\title{
POLA AKAD DALAM PEMBERDAYAAN EKONOMI MASYARAKAT PERANTAU ATAR
}

\author{
Maisarah Leli ${ }^{1}$, Farida Arianti² \\ ${ }^{1}$ STAI-YAPTIP Pasaman \\ e-mail: maisarah.leli@yahoo.co.id \\ ${ }^{2}$ IAIN Batusangkar \\ e-mail: arianti_ida@yahoo.co.id
}

\begin{abstract}
This paper discusses about the pattern of contracts in the economic empowerment of the Atar migrant community. Many migrants are not easy to get a job that later nomads can be independent. They are looking for work to other areas to be able to get a decent job that will provide their lives. In this section, the writer takes a qualitative descriptive approach by describing the contract pattern in empowerment carried out by the nomads, while the technique is snowball sampling in interviewing the main character until the information obtained at the saturated level, no more new information becomes data in this paper. The results achieved were that the nomads patterned contracts that were used in empowering the nomads community with qiradh contracts, and grants.
\end{abstract}

Kata kunci: pola akad, pemberdayaan ekonomi, perantau Atar.

\section{PENDAHULUAN}

$\mathcal{M}$ arantau merupakan salah satu filosofi budaya Minangkabau yang mengandung tiga unsur yakninya unsur ekspansi wilayah, perpindahan penduduk, dan ekonomi. Budaya merantau merupakan nilai yang hidup dan berkembang serta hubungan merantau dengan masyarakat adat Minangkabau saling berintegrasi yang tidak dapat dipisahkan. (Sumanto, 2018) Pada awalnya marantau berfungsi sebagai ekspansi wilayah yang dikenal dengan manaruko. Manaruko tidak hanya untuk kepentingan memperluas tanah manah, namun untuk menetap di rantaurantau baru disebabkan masyarakatnya telah banyak. Seperti manaruko Sungai Jambu terus Bungo Satangkai oleh Datuak Katamangguangan, Sedangkan Datuak Parpatiah Nan Sabatang manaruko nagari
Limo Kaum. (Ibrahim, 2009) lahan-lahan baru yang subur untuk ditempati, semenjak saat itulah luhak terbentuk. Luhak merupakan ikatan "politikekonomi dan budaya" Setiap nagari yang terdapat dalam luhak. Rantau merupakan daerah kolonisasi yang mana tetap memelihara ikatan politik, ekonomi, budaya dengan luhak. Sesuai dengan pepatah "Luhak dibari bapanghulu, rantau dibari rajo". (Saydam, 2010: 42)

Perubahan makna merantau dari manaruko menjadi invansi wilayah, hal ini terjadi ketika Minangkabau diperintah oleh Kerajaan Pagaruyung pada abad ke 14. Pola ini diadopsi dari Kerajaan Majapahit di Pulau Jawa. (Navis, 1984: 7) pola yang dipakai di Minangkabau ialah wilayah rantau yang dipimpin oleh rajaraja bawahan yang tunduk kepada 
Pagaruyung, dan wilayah luhak dipimpin oleh Penghulu.

Komoditi utama daerah rantau kala itu ialah lada, rantau memusatkan tenaga dan usaha untuk memproduksi hasil bumi yang penting lainnya. (Mansoer, 1970: 40) Para saudagar dari negeri asing berdatangan untuk transaksi komoditi tersebut. Daerah yang pada mulanya sebagai produsen komoditi lada berkembangan sebagai pusat ekonomi- budaya dan politik. Hubungan dagang yang dijalin antara daerah rantau dengan para padagang asing menimbulkan kontak budaya yang dikenal dengan asimilasi. Penghasil komiditi lada dikala itu ialah Kampar kiri dan kanan, Sungai Dareh/ Batang Hari.

Pada tahun 1950-1970 masyarakat Minangkabau merantau menyebar kelau wilayah Minangkabau, hal ini dipengaruhi kondisi sosial politik Indonesia dikala itu, yang mana kembalinya Jakarta menjadi ibukota mempengaruhi pemimpinpemimpin untuk keluar dari hutan dan pindah ke Jakarta. Perpindahan masyarakat Minangkabau dikala itu bertujuan di antaranya: mengikuti pemimpin- pemimpin yang beranggapan bahwa kehidupan di Jakarta lebih baik dari pada di kampung halaman, mengicar kedudukan dan posisi di berbagai kementrian dan departemen, dalam rangka mencari pekerjaan dan berdagang, dan adapula pelajar Minangkabau yang pergi untuk melanjutkan studi di berbagai universitas, karena belum ada universitas yang didirikan di pulau- pulau lainnya. Pada saat itu sejumlah penumpang berdesakan di Teluk Bayur dalam rangka mencari posisi/ kedudukan, pekerjaan atau pembelajaran di kota Jakarta. (Naim, 2013: 98)
Masyarakat Minangkabau bertepatan di Kenagarian Atar, Kecamatan Padang Gangtian, Kabupaten Tanah Datar banyak yang merantau dengan mengadu nasib pada usaha fotokopi. Mereka merantau ke berbagai daerah terutama di daerah pulau Jawa.

Pada umumnya, siapa saja yang merantau dari masyarakat Atar serta kemana saja mereka banyak dan merata bergerak di bidang jasa usaha fotokopi, bahkan keseragaman usahanya tersebut mereka telah membuat tugu fotokopi yang terletak di perkampungan Atar dalam rangka memperkenalkan usaha mereka kepada masyarakat kampungnya dan kepada orang lain, seperti gambar di bawah ini:

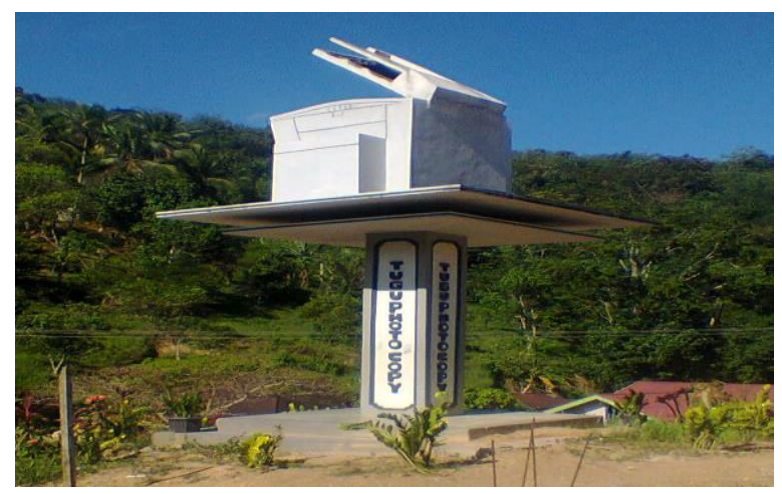

Gambar: Tugu fotocopi di Atar

Untuk itu, dalam merintis usaha fotocopi ini, tentunya mereka berusaha membangun relasi dengan masyarakat yang sudah dulu berhasil dalam usaha fotocopi, hubungan tersebut dalam bentuk bimbingan usaha, ataupun dalam bentuk pinjaman modal. Untuk itu lah, penulis akan membahas tentang pola akad dalam pemberdayaan ekonomi masyarakat Atar. 


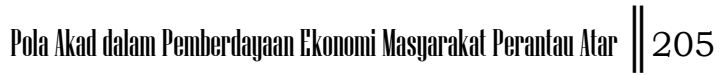

\section{METODE PENELITIAN}

Penelitian ini mengambil lokasi masyarakat Atar di perantauan yang berada di wilayah Kota Bandung Provinsi Jawa Barat dan wilayah sekitarnya yang berada di Pulau Jawa. Pengumpulan data dilakukan dengan berbagai teknik pertama wawancara untuk mengetahui pemberdayaan ekonomi masyarakat perantau Atar, demikian juga penulis mengumpulkan sumber data sekunder berupa artefak yakni tugu fotokopi.

Teknik Pengumpulan Data berikutnya adalah trianggulasi data. Triangulasi data adalah teknik pengumpulan data yang bersifat mengkonfrimasikan wawancara satu dengan wawancara kedua sekaligus mengamati artefak/ tugu fotokopi serta dokumendokumen yang mendukung yang berada di wilayah Nagari Atar, selanjutnya penulis mewawancari para perantau Atar yang berada di Bandung dan keluarganya untuk mendapatkan informasi mengenai pola pemberdayaan masyarakat perantau Atar terhadap karyawannya. Dan teknik analisis data diawali dengan analisis Domain yaitu pengelompokan dari proses unityzing berdasakan keyword yang ditemukan dalam life history. Langkah selajutnya analisis kategorial yang menjabarkan ciri- ciri masing masing domain dan taksonomi yang menjelaskan hubungan antar domain, sehingga pada akhirnya dapat memaparkan strategi dan cara pemberdayaan ekonomi masyarakat perantau Atar.

\section{PEMBAHASAN}

1. Masyarakat Atar Dan Kebudayaannya

Nagari Atar merupakan salah satu Nagari yang terletak di Kecamatan Padang Ganting, Kabupaten Tanah Datar. Nagari ini terletak pada $00^{\circ} 32^{\prime}$ LS- $00^{\circ} 46^{\prime}$ LS dan $100^{\circ} 44^{\prime}-100^{\circ} 53^{\prime}$ BT dengan ketinggian 500 dari permukaan laut. Temperatur $30^{\circ} \mathrm{C}$ dengan curah hujan $1.300 \mathrm{~mm}$ pertahun (Ganting, 2015: 5). Secara Administratif, batasbatas Nagari Atar adalah sebagai berikut: Sebelah Utara berbatasan dengan Nagari Tanjung Barulak. Sebelah Selatan berbatasan dengan Talawi Kota Sawahlunto. Sebelah Barat berbatasan dengan Padang Ganting. Sebelah Timur berbatasan dengan Nagari Taluk dan Pangian. (Atar W. N. 2015: 3)

Topografi berbukit-bukit sehingga pertanian khususnya sawah mengandalkan irigasi tadah hujan. Luas tanah menurut penggunaannya adalah sebagai berikut; sawah pengairan $45 \mathrm{Ha}$, sawah tadah $255 \mathrm{Ha}$, perkebunan $1560 \mathrm{Ha}$, hutan 325. (Ganting, 2015: 4) Seluruh potensi ini dikembangkan menjadi pertanian rakyat yang sangat menonjol yakninya: padi, kelapa, jeruk nipis, dan karet. Secara ekonomis memang agak sulit mengembangkan pertanian di Nagari Atar karena topografinya.

Kondisi ekonomi Nagari Atar umumnya bergerak di bidang pertanian, yang menjadi komoditi unggulan ialah karet dan saat ini telah menghasilkan \pm 15 ton karet. Adapun komoditi lainnya berupa padi \pm 10 ton, kacang kedelai \pm 5 ton, cokelat \pm 9 ton, 
pinang \pm 3 ton, cengkeh 5 ton, dan kulit manis 3 ton. (Ganting, 2015: 26-27)

Sebuah falsafah di Minangkabau "Sayang dek anak dilacuiki, sayang $k a$ kampung ditinggakan" (sayang pada anak dipukul, sayang pada kampung ditinggakan) sayang pada anak bukan cara untuk dimanjakan, begitupula dengan kampung halaman cari dahulu ilmu dan pengalaman yang dapat disumbangkan pada kampung. (Sayuti, 2009: 92) Maksudnya orang minang bila merantau mambao ilmu dengan pangalaman, seperti contoh oleh perantau Atar yang dipelopori oleh Yuskar dalam bidang usaha fotokopi dan mengembangkan kerjasama di kalangan masyarakat Nagari Atar, agar orang-orang yang sekampungnya bisa mencoba kenikmatan hidup seperti yang telah dialaminya selama ini.

Kaum/kelompok hidup mereka secara bersama-sama mempertahankan hidup dengan memelihara keadaan atau kedudukan yang sudah dimiliki. Dalam sikap mempertahankan hidup dan lingkungannya berpola babiliak ketek babiliak gadang (berkamar kecil, berkamar besar) sangat dipegang teguh. lebih diutamakan ialah sanak saudara, kemudian orang sekampung. Selanjutnya orang sepersukuan. Orang yang sama suku belum tentu sekampung halaman atau senagari. Terakhir barulah lingkungan senagari. (Navis, 1984: 81)

Adapun pola kekerabatan Minangkabau adalah sistem kekerabatan matrilineal yang ditarik dari garis keturunan ibu, perempuan dalam sistem ini merupakan penyambung garis keturunan dalam kerabatnya agar tidak terputus. Hal ini berhubungan dengan harta pusaka, kalau keluarga tersebut tidak memiliki anak perempuan, maka dianggap punah. Keturunan yang berlangsung lama sekali, mulai dari satu induk, berkembang menjadi saparuik, dari saparuik, berkembang menjadi sasuku. (Eva, 2013: 165) Kekerabatan menjadi daya ikat dan menyatukan individu-individu ke dalam suatu jaringan yang kompleks. (Navis, 1984: 7)

\section{Akad dalam Ekonomi Islam}

\section{a. Pengertian Akad}

Lafaz akad berasal dari bahasa Arab al-'aqd yang berarti perikatan, perjanjian, dan permufakatan, yang sinonimnya yaitu:

1) Ja'ala 'uqdatan, yang artinya: menjadikan ikatan

2) Akkada, yang artinya: memperkuat

3) Lazima, yang artinya: menetapkan (Ibrahim Anis, 1972: 613-614)

Perjanjian atau kontrak dalam istilah hukum Islam biasa disebut dengan "akad". Kata akad dalam istilah bahasa berarti ikatan dan tali pengikat. (Azzam, t.th: 15) Secara etimologi, akad berarti ikatan antara dua perkara, baik ikatan secara nyata maupun ikatan secara maknawi, dari satu segi maupun dari dua segi. Tidak boleh kesepakatan untuk menipu orang lain, transaksi barang-barang yang diharamkan dan membunuh seseorang. (Hasan, 2003: 101) Sedangkan secara terminologi akad adalah

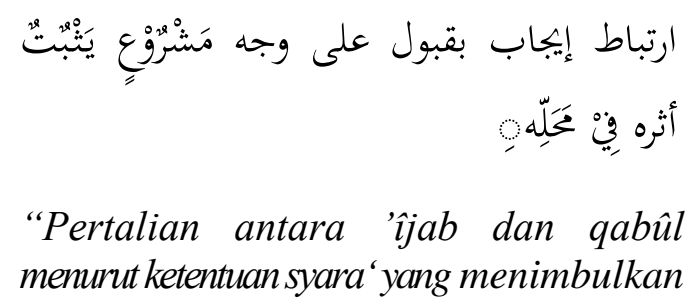


akibat hukum pada objeknya." (Ibnu Abidin, t.th: 255)

Secara umum, pengertian akad dalam arti luas hampir sama dengan akad dari segi bahasa menurut pendapat ulama Syâfi'iyah, Mâlikiyah dan Hanafiyah yaitu segala sesuatu yang dikerjakan oleh seseorang berdasarkan keinginannya sendiri, seperti wakaf, talak, pembebasan atau sesuatu yang pembentukannya membutuhkan keinginan dua orang seperti jual-beli, perwakilan, dan gadai. (Ibnu Abidin, t.th: 255)

b. Bentuk Akad (Zuhayliy, 1984: 106)

Salah satu bentuk akad bersifat mengikat bagi pihak- pihak yang melangsungkan akad terdiri tiga macam yakninya:

a. Akad yang mengikat dan tidak bisa dibatalkan sama sekali. Akad perkawinan tidak boleh dibatalkan, kecuali dengan cara- cara yang dibolehkan oleh syara:

b. Akad yang mengikat, tapi boleh dibatalkan atas kehendak kedua belah pihak, seperti jual beli, sewamenyewa, perdamaian

c. Akad yang hanya mengikat salah satu pihak saja seperti akad rahn.

Jika dilihat dari sisi mengikat dan tidak mengikatnya jual beli shahih, para ulama fiqh membaginya dalam dua macam yaitu: (Zuhayliy, 1984: 241)

a. Akad yang bersifat mengikat bagi pihak- pihak yang berakad, sehingga salah satu pihak tidak boleh membatalkan akad itu tampa izin dari pihak yang lain.

b. Akad yang tidak bersifat mengikat terhadap pihak lain, seperti wakâlah, wadî'ah dan 'âriyah.

\section{Pemberdayaan Ekonomi}

\section{a. Konsep Pemberdayaan}

Pemberdayaan menurut bahasa berasal dari kata daya yang berarti tenaga/ kekuatan, proses, cara, perbuatan memberdayakan. (Pendidikan, KBBI, 2002: 242) Pemberdayaan adalah upaya yang membangun daya masyarakat dengan mendorong, memotivasi dan membangkitkan kesadaran akan potensi yang dimiliki serta berupaya untuk mengembangkannya. (Sulekale, 2014: 1) Sehubungan itu karakteristik manusia memiliki motivasi tinggi memandang beberapa hal yakni; pekerjaan yang bernilai ibadah, memandang pekerjaan perintah Allah sehingga timbul kehati-hatian, menghargai waktu, hemat, produktif serta menjaga kasih sayang sesama manusia. (Mujahidin, 2017: 155)

Pemberdayaan diarahkan guna meningkatkan ekonomi masyarakat secara produktif sehingga mampu menghasilkan nilai tambah yang tinggi dan pendapatan yang lebih besar. Upaya peningkatan kemampuan untuk menghasilkan nilai tambah paling tidak harus ada perbaikan akses terhadap empat hal, yaitu akses terhadap sumber daya, akses terhadap teknologi, akses terhadap pasar dan akses terhadap permintaan.

Ekonomi masyarakat adalah segala kegiatan ekonomi dan upaya masyarakat untuk memenuhi kebutuhan hidupnya (basic need) yaitu sandang, pangan, papan, kesehatan dan pendidikan. Pemberdayaan ekonomi 
masyarakat merupakan satu upaya untuk meningkatkan kemampuan atau potensi masyarakat dalam kegiatan ekonomi guna memenuhi kebutuhan hidup serta meningkatkan kesejahteraan mereka dan dapat berpotensi dalam proses pembangunan nasional. (Sulekale, 2014:1)

Rintuh (Rintuh, 2005: 85) ia mengatakan bahwa pemberdayaan ekonomi mewujudkan langkah-langkah nyata yang harus diupayakan agar pertumbuhan ekonomi rakyat berlangsung dengan cepat. Pemberdayaan ekonomi masyarakat dapat meningkatkan kehidupan masyarakat kearah yang lebih baik. (Suryana, 2006: 6)

Sedangkan Femi M. Gulan Tulusan dan Very Y. Londa pemberdayaan ekonomi adalah Pemberdayaan adalah bagian dari paradigma pembangunan yang memfokuskan perhatiannya pada semua aspek yang prinsipil dari manusia di lingkungannya, yakni mulai dari aspek intelektual (sumber daya manusia), aspek material dan fisik, sampai kepada aspek manajerial. Aspek-aspek tersebut bisa jadi dikembangkan menjadi aspek sosial-budaya, ekonomi, politik, keamanan, dan lingkungan. (Tulusan, 2014: 94)

Kesejahteraan masyarakat merupakan tujuan dari pembangunan ekonomi sesuai dengan pendapat para ahli dari aliran teori strukturalis. Bahwa strategi pembangunan di negara berkembang akan lebih baik berupa penciptaan lapangan kerja, reinvestasi, pemenuhan kebutuhan hidup pokok, dan semakin meningkatnya kemandirian dan kemampuan daerah dalam penyelenggaraan pembangunan, yang bermuara kepadatercapainya sasaran pertumbuhan ekonomi nasional dan daerah. (Santoso, 1998: 50)

Sejalan dengan pendapat di atas menurut Sumondiningrat dalam Femy M. G Tulusan (Tulusan, 2014, hal. 93)dalam rangka mencapai masyarakat yang sejahtera dibutuhkan strategi pembangunan yang berkelanjutan yang pada hakekatnya berorientasi kepada peningkatan kemakmuran dan kesejahteraan manusia. Pendapat di atas senada dengan pendapat yang diberikan oleh Chambers dalam (Kartasasmita, 1996: 6) Pemberdayaan masyarakat adalah sebuah konsep pembangunan ekonomi yang merangkum nilai-nilai sosial, konsep ini mencerminkan paradigma baru pembangunan, yakni yang bersifat "people-centered, participatory, empowering, and sustainable"

Seiring itu tanggung jawab yang melekat pada setiap perusahaan untuk penanaman modal guna menciptakan hubungan yang serasi, seimbang, dan sesuai dengan lingkungan, nilai, norma, dan budaya masyarakat setempat. Transaksi bisnis tidak lepas dari tujuan moral masyarakat yang menciptakaan kesejahteraan. (Turmudi, 2018)

Dari beberapa pengertian di atas dapat disimpulakan bahwa pemberdayaan ekonomi adalah peningkatan ekonomi masyarakat dengan mengarahkan/mengoptimalkan potensi- petensi yang ada di dalam masyarakat untuk mendapatkan kesejahteraan hidup yang lebih baik. 


\section{b. Upaya Pemberdayaan Ekonomi Masyarakat}

Dalam untuk meningkatan taraf hidup masyarakat, pemberdayaan ekonomi adalah dengan memberikan kesempatan kepada kelompok miskin untuk merencanakan dan melaksanakan program pembangunan yang telah mereka tentukan. Disamping itu masyarakat juga diberikan kesempatan untuk mengelola dananya sendiri, baik yang berasal dari pemerintah maupun pihak amil zakat, (Hutomo, 2000: 1-2).

Dalam pemberdayaan ekonomi masyarakat adapun tiga pilar yang saling mendukung agar terwujudnya program pemberdayaan masyarakat adalah pemerintah, swasta dan masyarakat yang hendaknya menjalin hubungan kemitraan yang selaras. (Hutomo, 2000: 2) Tujuan dari pemberdayaan ekonomi adalah untuk membentuk pribadi dan masyarakat menjadi mandiri, kemandirian tersebut meliputi kemandirian berfikir, bertindak dan mengendalikan apa yang mereka lakukan tersebut. Pemberdayaan masyarakat hendaknya mengarah pada pembentukan kognitif masyarakat yang lebih baik, untuk mencapai kemandirian masyarakat diperlukan sebuah proses.

Agar terwujudnya pemberdayaan ekonomi yang efektif serta bermanfaat bagi masyarakat miskin ada dua metode yang dapat diterapkan yaitu: (Hutomo, 2000: 38)

1) Membentuk generasi muda menjadi seorang penguasaha/ wiraswasta.
Dalam agama Islam, adapun cara dalam mengatasi kemiskinan adalah dengan berkerja secara maksimal dengan menggunakan modal serta potensi yang ada. Prase ini juga dapat disimpulkan bahwa dalam Islam sebaik- baik pekerjaan adalah wiraswasta. Adapun pembinaan yang dapat dilakukan untuk seorang wiraswasta adalah sebagai berikut. (Hutomo, 2000: 38)

a) Memberikan dukungan moril, adapun bentuk- bentuk dukungan moril adalah sebagai berikut:

(1)Pelatihan usaha, melalui pelatihan ini memberikan pemahaman terhadap konsepkonsep kewirausahaan dengan segala macam seluk beluk permasalahan yang ada di dalamnya. Tujuan pelatihan adalah untuk memberikan wawasan yang lebih menyeluruh dan aktual sehingga dapat menumbuhkan motivasi terhadap masyarakat di samping diharapkan memiliki pengetahuan taknik kewirausahaan dalam berbagai aspek.

(2)Permodalan

Permodalan adalah hal yang penting dalam dunia usaha. Pemberian modal melihat prospek usaha.

2) Dengan meningkatkan Pendidikan masyarakat.

Salah satu penyebab kemiskinan adalah kebodohan. maka oleh sebab itu agar terwujudnya kebodohan dengan peningkatan sektor pendidikan, 
karena secara umum kemiskinan bersifat "warisan", yang biasa orang tuanya miskin sehingga tidak mampu membiayai biaya pendidikan anaknya, dan hal ini juga akan menambah daftar kemiskinan esoknya. Adapun bentuk pemberdayaan dalam sektor pendidikan adalah memberikan bantuan berupa, zakat, hibah dan bantuan yang senada dalam bentuk seperti pemberian beasiswa. Zakat juga cara pemerintah untuk menekan angka kemiskinan. (Sahiba Abdullahi Ammani, 2014) Qardh Hasan sebagai sarana efektif dalam memberdayakan masyarakat miskin melalui BMT. (Widiyanto, 2011)

$$
\text { Ginanjar Kartasasmita }
$$

dalam Femy M.G Tulusan untuk memperdayakan masyarakat dapat dilihat dari tiga sisi yakninya (Tulusan, 2014)

1) Menciptakan iklim yang memungkinkan potensi masyarakat berkembang (enabling). Di sini titik tolaknya adalah pengenalan bahwa setiap manusia, setiap masyarakat, memiliki potensi yang dapat dikembangkan. Artinya, tidak ada masyarakat yang sama sekali tanpa daya, karena kalau demikian akan punah. Pemberdayaan adalah upaya untuk membangun daya itu, dengan mendorong, memotivasi, dan membangkitkan kesadaran akan potensi yang dimilikinya serta berupaya untuk mengembangkannya.

2) Memperkuat potensi atau daya yang dimiliki oleh masyarakat (empowering). Dalam rangka ini diperlukan langkah-langkah lebih positif, selain dari hanya menciptakan iklim dan suasana. Penguatan ini meliputi langkahlangkah nyata, dan menyangkut penyediaan berbagai masukan (input), serta pembukaan akses ke dalam berbagai peluang (opportunities) yang akan membuat masyarakat menjadi makin berdaya.

3) Dalam rangka pemberdayaan ini, upaya yang sangat pokok adalah peningkatan taraf pendidikan dan derajat kesehatan, serta akses ke dalam sumber-sumber kemajuan ekonomi, seperti; modal, teknologi, informasi, lapangan kerja, dan pasar. Masukan berupa pemberdayaan ini menyangkut pembangunan prasarana dan sarana dasar, baik fisik seperti; irigasi, jalan, dan listrik, ataupun sosial seperti; sekolah dan fasilitas pelayanan kesehatan, yang dapat dijangkau oleh masyarakat pada lapisan paling bawah, serta ketersediaan lembaga-lembaga pendanaan, pelatihan, dan pemasaran di perdesaan, di mana terkonsentrasi penduduk yang keberdayaannya cukup minim.Untuk itu perlu ada program khusus bagi masyarakat yang kurang berdaya, karena program-program umum yang berlaku untuk semua, tidak selalu dapat menyentuh lapisan masyarakat ini.

\section{PEMBERDAYAAN EKONOMI MASYARAKAT ATAR}


Pemberdayaan ekonomi pada perantau Atar sangat bervariasi diantara adalah sebagai berikut:

1. Perantau termotivasi untuk merubah kehidupan.

Dalam memulai usaha fotokopi, Yuskar pada mulanya berfikir untuk perekonomian masyarakat Atar, karena ia telah menekuni usaha fotokopi, ia menolong karib-kerabatnya di kampung untuk ikut bersamanya ke perantauan, maka pada mulanya ia membawa Syafi'i, Yusparman, Bachtiar, dan Zainal. Mereka merupakan pencetus usaha fotokopi dan menguasai fotokopi di wilayah Jawa Barat, Jawa Tengah, Yogyakarta, dan Medan. Pengembangan usaha fotokopi didukung oleh solidaritas keluarga Yuskar untuk mengembangkan usaha fotokopi bagi orang kampungnya, yang sama-sama saling menguntungkan masingmasing pihak. Adapun karib kerabat adik, ipar, anak kemenakan, orang kampung membawa ikut melanjutkan, meniru serta mengembangkan bisnis pendahulunya.

Hal ini penulis peroleh dari keterangan yang diberikan oleh (Zainal, 2016) seorang perantau Atar yang berkecimpung dalam usaha fotokopi

"Nagari Atar tidak begitu terkenal di Provinsi Sumatera Barat maupun Kabupaten Tanah Datar, akan tetapi nagari ini terkenal di Bandung kemudian menyebar ke Yogyakarta dan Semarang.

Awalnya Yuskar membawa orang kampung sebagai penolong dalam pekerjaannya di usaha fotokopi dengan sekalian memberikan tempat pekerjaan bagi sanak familinya, keluarga dan kampung halaman. Seiring itu, para karyawan tidak hanya semata memcari pekerjaan dengan orang lain, akan tetapi ia berusaha agar terlepas dari bosnya".

Hal ini dikuatkan dengan keterangan yang diberikan oleh Yusparman, ia berkata (Yusparman, 2016)

"Adapun diantara sesepuh fotokopi Atar adalah Yuskar, Zainal dan saya sendiri. Hal ini dapat mempermudah warga Atar untuk berkecimpung dalam bisnis ini, karena yang menjual mesin fotokopi adalah warga Atar sendiri, sehingga warga Atar dapat membeli mesin fotokopi secara cicilan. Biasanya perantau pemula mencari kerabat-kerabatnya di perantauan khususnya Bandung dan sekitarnya yang membuka usaha fotokopi, para pemilik fotokopi memprioritaskan karyawannya berasal dari Atar, kebanyakan karyawannya adalah masyarakat kampung yang putus sekolah dan tidak memiliki pekerjaan, mereka dibina dengan keahlian fotokopi berupa penjilidin, jual beli alat tulis dan perbaikan mesin. Para perantau Atar ini ingin bekerja serta ingin merubah taraf hidup yang lebih baik disamping ilmu yang bermanfaat".

Faktor lain yang diambil oleh warga Atar ialah mencari pekerjaan, sehingga pengetahuan/pekerjaan yang mudah didapat oleh warga perantau Atar adalah fotokopi yang mudah didapatkan melalui hubungan kekerabatan yakninya sesama warga Atar. Disamping itu dalam usaha ini memerlukan banyak tenaga, sehingga mereka merekrut anak semang-nya dari warga kampung, sehingga cara ini merupakan dianggap paling efektif untuk mengembangkan serta menguasai usaha fotokopi. Usaha fotokopi dianggap sebagai tujuan perantauan, sehingga mereka tidak susah mencari pekerjaan 
setibanya di perantauan, di tempat rantau sudah ada tempat bekerja, siapa yang dituju, sekaligus bekerja dengan saudara, famili dan orang kampung

Dalam pembinaan perantau Atar ada dua pihak yang berkepentingan, pertama pihak keluarga menginginkan anaknya bekerja dengan orang lain, hal ini terlihat ketika seseorang pergi merantau, pihak keluarga masih memiliki hubungan komonikasi dengan perantau tersebut, keluarga di kampung mendatangi atau menemui perantau yang pulang ke kampung halaman, kemudian pihak keluarga bercakap-cakap dengan para perantau tersebut dengan tujuan membawa anak atau kemenakannnya ke perantauan. Kesempatan pulang basamo digunakan oleh pihak keluarga untuk memperkenalkan anak/kemenakannya dengan para perantau sekaligus menjalin hubungan anak semang dengan induk semang. Induk semang yang mencari orang kampung bertanggung jawab atas ongkos ke rantau serta kebutuhan sehari- hari. Hal ini terlihat dari wawancara yang penulis lakukan dengan seorang perantau Atar Wahyu Hidayat (23) perantau Atar yang membuka usaha fotokopi di Pekanbaru, ia berkata:

"Ketika masyarakat Atar Pulang Basomo pada tanggal 25 Mei 2016, saya mendatangi kantor Wali Nagari Atar untuk menyambut para perantau bersama mamak saya, ketika itu saya berjumpa dengan Jafri, seorang perantau Atar yang juga membuka fotokopi di Pekan Baru, Jafri merupakan kenalan lama dari mamak saya, mereka pun bercakap- cakap mengenai perkembangan bisnisnya di perantauan, Jafripun mengatakan bahwa ia membutuhkan seorang karyawan yang bisa membantu pekerjaannya, dan ketika itu saya masih pengganguran, dan mamak saya memintanya agar mambawa saya ke Pekanbaru, agar bisa membantunya dalam bisnis tersebut, dan ia pun menyetujuinya, dan sejak saat itulah saya bekerja dengan Jafri". (Hidayat, 2016)

Kedua, pihak perantau mendatangi sanak familinya diperantauan, agar dicarikan pekerjaan yang mampu ia kerjakan, sekaligus magang untuk bisa mengoperasikan mesin fotokopi, hal ini terlihat pada wawancara yang penulis lakukan dengan Ade Saputra (54), ia berkata"

"Ia merantau mengikuti mamaknya, untuk bekerja sekaligus belajar mengenai fotokopi, ketika ia merasa sanggup untuk mandiri, ia membeli mesin dari Yuskar pada tahun 2002, ia membuka usaha fotokopi di Sukabumi dan memiliki karyawan sebanyak 2 orang yakniny, salah satunya adalah adik kandungnya. Menurut Ade Saputra, ia hanya memiliki karyawan tetap selama 2-3 tahun, kemudian para karyawan tersebut umumnya pergi, untuk membuka usaha fotokopi sendiri (Saputra, 2016).

Orang Atar yang menjadi anak semang umumnya bertujuan ingin mengubah kehidupan serta mendapatkan ilmu mengenai teknik mesin, karena pada mulanya warga Atar yang merantau tidak memiliki keahlian sedikitpun. Yuskar sebagai pencetus fotokopi membawa orang Atar sebagai penolong dalam pekerjaannya diusaha fotokopi dan sekaligus memberikan lapangan pekerjaan bagi sanak famili, serta mendorongnya untuk bisa mandiri (terlepas dari induk semangnya). Dalam hal ini, para perantau pemula dianggap sebagai "Orang yang bodoh 
mengenai mesin fotokopi, maka oleh sebab itu ia membutuhkan seorang pengampu yang berfungsi untuk mengemblengnya dan bertanggung jawab atas pekerjaan yang ia lakukan sampai ia mampu untuk melakukannya sendiri.

Warga Atar yang baru tiba diperantauan dianggap sebagai keluarga, mereka dibina serta diberi pengetahuan tentang fotokopi seperti penjualan alat- alat tulis, fotokopi dan penjlilidan, tata cara perbaikan mesin, serta pengetahuan mengenai bagian administrasi keuangan. Dan biasanya mereka magang selama waktu tertentu sampai ia sanggup untuk membuka fotokopi sendiri, biasanya waktu yang mereka butuhkan untuk membuka fotokopi sendiri sekitar lima tahun/ lebih (Yusparman, 2016). Bagi pemula yang berstatus magang, selain ilmu yang mereka dapatkan, mereka juga memperoleh fasilitas berupa gaji, makan beserta tempat tinggal, sedangkan kalau saudara, mereka tinggal lebih bebas sebatas untuk kebutuhan sendiri

2. Memulai pekerjaan dari bawah

Perantau melakukan pekerjaan memulai dari pekerjaan yang ringanringan dengan mengamati dan mencoba untuk melakukannya. Dari ketidaktahuannya cara bekerja dalam usaha yang baru ditempuhnya, dan induk semang belum berani menyerahkan sepenuhnya tanpa diajari dan dibimbing terlebih dahulu, karena akan beresiko terhadap usaha. Yuskar membawa sanak saudaranya, familinya menurut tahapan perjalanan waktunya, yang mana sebelumnya ia membenahi/mencukupkan pada adekadeknya sendiri, terus iparnya, saudara sesuku dan sekampungnya. Syamsiwar, Erman, Yunizar Apalagi pekerjaannya semakin besar yang menghendaki kebutuhan tenaga kerja.

Memulai dari bawah akan mengkokohkan usahanya sekalipun rintangan yang akan dihadang seperti mesin rusak, fotokopi macet, pendapatan kurang. Karena mereka sudah belajar dari yang kecil dan tahu apa yang dilakukannya untuk selanjutnya. Sebaliknya jika tidak demikian langsung saja berusaha tanpa dari bawah, ketika hambatan usaha tiba, akan goyang usahanya karena bekal ilmu dan pengalamn yang diperolehnya belum ada dan belum mapan.

Memberikan pengetahuan dasar tentang bagaimana cara memfotokopi, stel mesin, bongkar mesin, memperbaiki kerusakan fotokopi, penjilitan. Pengetahuan, pembinaan terbuka lebar bagi siapa yang mau maju/berkembang, sehingga mereka yang bekerja benar-benar paham dan menguasai usaha yang ditekuninya. Waktu masa bekerja tergantung karyawan/perantau pemula sampai dia berniat untuk mandiri. Pengetahuan tersebut amat penting agar usahanya nanti dapat bertahan karena banyak orang lain membuka usaha fotokopi tanpa mempelajarinya secara maksimal, maka ketahanan produksi bisa rapuh karena bnyaknya biaya produksi yang akan ditanggung.

3. Diberi pengetahuan terkait pekerjaan yang dihadapinya 
Orang Atar yang menjadi anak semang umumnya bertujuan ingin mengubah kehidupan serta mendapatkan ilmu mengenai teknik mesin, karena pada mulanya warga Atar yang merantau tidak memiliki keahlian sedikitpun. Yuskar sebagai pencetus fotokopi membawa orang Atar sebagai penolong dalam pekerjaannya diusaha fotokopi dan sekaligus memberikan lapangan pekerjaan bagi sanak famili, serta mendorongnya untuk bisa mandiri (terlepas dari induk semangnya). Dalam hal ini, para perantau pemula dianggap sebagai "Orang yang bodoh mengenai mesin fotokopi, maka oleh sebab itu ia membutuhkan seorang pengampu yang berfungsi untuk mengemblengnya dan bertanggung jawab atas pekerjaan yang ia lakukan sampai ia mampu untuk melakukannya sendiri.

"Warga Atar yang baru tiba diperantauan dianggap sebagai keluarga, mereka dibina serta diberi pengetahuan tentang fotokopi seperti penjualan alat- alat tulis, fotokopi dan penjlilidan, tata cara perbaikan mesin, serta pengetahuan mengenai bagian administrasi keuangan. Dan biasanya mereka magang selama waktu tertentu sampai ia sanggup untuk membuka fotokopi sendiri, biasanya waktu yang mereka butuhkan untuk membuka fotokopi sendiri sekitar lima tahun/ lebih (Yusparman, 2016) Bagi pemula yang berstatus magang, selain ilmu yang mereka dapatkan, mereka juga memperoleh fasilitas berupa gaji, makan beserta tempat tinggal, sedangkan kalau saudara, mereka tinggal lebih bebas sebatas untuk kebutuhan sendiri"

4. Perantau diberi bantuan modal.

Pelaksanaan yang dilakukan bapak Yuskar adalah dengan cara memodali atau membina warga sekampunnya baik yang berasal dari suku Caniago dan suku- suku lainya yang terdapat di wilayah Atar, memang Yuskar dengan memperlihatkan pemberian modal berupa mesin fotokopi, tinta, kertas. mesin potong dll.

Di perantauan para keluarga Yuskar ini sebelum mandiri diberilah modal dengan cara yang telah penulis paparkan di atas, itu lah yang dinamakan sistem malakok. Sistem malakok yang dilakukan oleh para penggagas fotokopi ini dengan bekerja ditempat yang sudah ada. Dengan mengembangkan usaha yang ada sehingga pemilik usaha fotokopi sudah bisa menilai kinerja dari karyawan yang didominasi oleh sanak keluarganya ini untuk mengembangkan usaha. Karyawan itu membuka cabang dengan pembiayaan awal dari pemilik utama. Pemilik utama selaku mamak akan memberikan modal berupa, mencarikan tempat atau menyewa tempat usaha, membelikan mesin fotokopi baru/seken dan segala kebutuhan untuk usaha tersebut.

Penguatan permodalan, memberikan sebagian hartanya untuk dijadikan modal yang mana akan diganti menurut waktu kesanggupan membayar. Pinjaman tersebut tanpa ada riba/bunga. Disamping itu memberikan sepenuhnya secara cumacuma dalam hal biaya yang ringanringan. Pengutan permodalan ini dilakukan oleh perantau Atar

Pemilik usaha fotokopi memberikan pinjaman sebagian hartanya untuk dikembalikan bila dia sudah sanggup membayarnya, ini bernilai dengan uang. Yuskar mencarikan mesin fotokopi baru yang dibeli dari luar negeri lalu diberikan kepada 
karyawannya yang mau mandiri. Bila pembuka usaha baru tersebut telah memiliki uang dia dapat membayarnya atau mengasur pinjaman yang senilai harga mesin yang dibeli oleh Yuskar. Pinjaman hal seperti ini menuntut adanya penggantian atau bahasa fiqhnya muqaradhah/mengqiradhkan, memberikan sebagian harta kepada orang lain yang menjadi tanggungjawabnya untuk mengantikan dalam jumlah yang senilai dalam kegiatan pengembangan ekonomi bagi pemula. Hal ini didukung oleh keterangan yang diberikan oleh (Tamrin, 2016) ia menjelaskan bahwa:

"Pada mulanya ia bekerja dengan Yusparman, ia merupakan adik kandung dari Yusparman. Ketika ia menjadi anak semang dari Yusparman, ia dipercaya oleh induak samang-nya sendiri, hal ini disebabkan karena faktor kekeluargaan, karena ia dipercaya oleh induak samangnya sendiri, maka ia diberikan pinjaman modal oleh kakaknya, modal tersebut dalam diangsur secara cicilan. Pinjaman modal tersebut dalam bentuk menghutangi mesin potokopi. Ia juga menambahkan bahwa apabila ada warga masyarakat Atar yang ingin membuka usaha fotokopi dapat juga ditolong dengan pembelian mesin fotokopi dan masyarakat tersebut dapat mengasur pembayarannya secara cicilan."

Hal ini didukung dengan keterangan yang diberikan oleh (Yasrizal, 2016) seorang perantau Atar yang buka usaha fotokopi di Sukabumi ia berkata

"Ia pada mulanya ia merantau mengikuti mamak-nya dan kakaknya, yang bergelut dengan usaha fotokopi, Ia mandari pada tahun 2007, ia mandiri setelah mendapatkan pinjaman berupa kontarkkan, pinjaman tersebut dapat dibayarkan secara cicilan, dan batas waktu pembayaran utang tersebut tidak ditentukan, sehingga para pengutang dapat membayarnya, ketika ia merasa lapang, dan pembayaran utang tersebut tidak disertai dengan penambahan, dan jumlah setoran yang wajib dibayarkan, tidak ditentukan jumlahnya, sehingga tidak memberatkan pihak penerima utang, sehingga ia dapat membayarkannya sesuai dengan pendapatannya. "

Hal ini diperkuat oleh keterangan yang diberikan oleh (Jefrizal, 2016), seorang perantau Atar yang merantau di Cikarang, Bekasi ia berkata

"Ia belajar fotokopi dengan Jamarlis, sekaligus menjadi karyawannya. Ia dibina sampai mandiri oleh Jamarlis dalam bentuk pemberian ilmu mengenai mesin fotokopi, serta pemberian pinjamam modal yang pembayarannya dapat dicicil selama dua bulan, dan biasanya pinjaman hanya diberi 1 kali, tanpa adanya penambahan utang, para induak samang biasanya mereka membantu karena hubungan kekerabatan yakninya sesama orang Atar, dan juga tergantung pada hubungan antara anak samang dan induak samang-nya. Namun secara spesifik bantuan tersebut diberikan kecendrungan membantu tersebut disebabkan karena hubungan keluarga, sanak famili barulah orang se-Nagari Atar."

"Pinjaman tersebut hanya diberikan satu kali, apabila modal habis maka biasanya tidak akan diberikan lagi, hal ini membuat para pemula bergiat serta bertanggung jawab terhadap usahanya. Bentuk lain pinjaman yang diberikan adalah mengutangkan mesin fotokopi kepada adiknya agar adiknya bergiat bekerja".

"Pembayaran utang tersebut melihat kepada kesanggungapan penerima utang serta lingkungan kerjanya, pembayaran 
dapat dilakukan dengan mengasur utang sedikit-demi sedikit, walauupun demikian para penghutang berkewajiban membayarnya, serta pembayarannya tanpa disertai bunga."

Hal ini diperkuat oleh keterangan yang diberikan oleh (Zainal, 2016), seorang perantau Atar yang merantau di Bandung, Bekasi ia berkata

"Bantuan yang diberikan berupa hutang mesin fotokopi, namun apabila utang tersebut diberikan kepada karib kerabat, mereka diberikan arahan bahwa modal tersebut harus pandai- pandai mempergunakannya, dan jangan sampai pinjaman tersebut habis, jika pinjaman itu habis, maka ia tidak akan diberikan lagi".

Hal ini diperkuat oleh keterangan yang diberikan oleh (Yusman, 2016), seorang perantau Atar, ia berkata"

"Kemudahan ia peroleh dari Induak samang adalah dengan memberi jalan serta mendapatkan jaminan dengan cara mesin dibayar dengan angsur menurut kesepakatan dua belah pihak. Seperti contoh ia berhutang sebanyak Rp. 35.000.000,dibayar $10 x$ dan tinggal sisanya $R p$. 25.000.000,- dibayar dalam jangka waktu yang disepakati, dan tidak adanya penambahan utang serta tidak ada penarikkan mesin bila jangka waktu tempo belum lunas".

Pemberian Hibah, yakni memberikan sesuatu yang semata keikhlasan untuk membantu. Hal ini biasanya dalam bentuk ala kadarnya, seperti kertas A4 sebanyak dua rim, tinta 3 bungkus, rol, laminating dan lain-lain. Artinya jumlah nominalnya tidak terlalu besar. Hal ini diperkuat dengan keterangan yang diberikan oleh (Rafi'ah, 2016) seorang perantau Atar yang membuka fotokopi di Bandung, ia berkata
"Dia merupakan saudara kandung dari dari Yuskar, dan membuka fotokopi di kawasan Bandung di Jalan Pati Ukur di Jati Longo." "Dalam membuka usaha fotokopi, ia memperoleh modal dengan mesin yang diberikan oleh Yuskar, Yuskar memberinya mesin karena mereka memiliki hubungan kekerabatan. Yuskar memberikannya sebuah mesin fotokopi secara cuma-Cuma. Orang yang memulai usaha fotokopi biasanya menggunakan mesin bekas, pemberian dari induak semang-nya, ada dalam bentuk utang, sedangkan bagi Yusparman, ia ada memberikan modal secara cuma-cuma dan dalam bentuk utang. Pemberian tergantung dalam hubungan kerabat, semenda."

Keterangan ini didukung oleh hasil wawancara yang penulis lakukan dengan yang diberikan oleh (Jefrizal, 2016), seorang perantau Atar yang merantau di Cikarang, Bekasi ia berkata:

".... Dalam pengembangan usaha fotokopi adakalanya mesin ia dapatkan secara Cuma- Cuma dari Jamaris di samping modal yang ia peroleh dari hasil gajinya selama 6 tahun bekerja dengan Jamaris".

Hal ini diperkuat dengan keterangan yang diberikan oleh (Yusparman, Pola Pembinaan Perantau Atar di Bandung, 2016) seorang perantau Atar yang membuka fotokopi di Bandung, ia berkata"

"Ia membuka usaha fotokopi di Semarang, dan mempunyai seorang anggota yang bernama Rajiman Chaniago (seorang perantau yang berasal dari Atar), Rajiman merupakan seorang teknisi mesin, ketika dia mandiri, maka saya memberinya modal sebuah mesin fotokopi. Hubungam antara Yusparman dengan Rajiman ialah hubungan satu kampung, dan merupakan tangan kanan dari Yusparman." 


\section{PENUTUP}

\section{Kesimpulan}

Masyarakat perantau yang berasal dari Kenagarian Atar Kecamatan Padang Ganting Kabupaten Tanah Datar dominan mendapatkan pekerjaan yang mapan dari sisi skill dan pengetahuan sehingga bisa mandiri. Masyarakat perantau secara langsung memperdayakan ekonomi masyarakat kampung halamannya dengan akad qiradh hibah dalam pemberi bantuan modal berupa skill/keahlian dan meteri.

\section{Saran}

Tulisan ini bisa dijadikan rujukan bagi masyarakat yang ingin memperdayakan ekonomi, dalam bentuk pengelolaan sumberdaya finansial secara mandiri tanpa adanya campur tangan dari pihak swasta maupun dari pemerintah.

\section{DAFTAR PUSTAKA}

Atar, K. W. (t.thn.). Profile Nagari Atar.

Atar, W. N. (2015). Profile Nagari Atar. Atar.

Azzam, A. A. (t.th). Figh Muamalat Sistem Transaksi Dalam Islam. Jakarta: Sinar Grafika Offset.

Budiman, N. (2016). Masyarakat Atar, wawancara, 23 November.

Eva, Y. (2013). Perubahan Budaya Hukum Masyarakat Minangkabau. Yogyakarta: Fakultas Hukum Universitas Gadjah Mada.
Ganting, K. S. (2015). Kecamatan Padang Ganting Dalam Angka 2015. Batusangkar: BPS Kabupaten Tanah Datar.

Hasan, M. (2003). Berbagai Macam Transaksi dalam Islam. Jakarta: PT RajaGrafindo Persada.

Hidayat, W. (2016). Pengusaha Fotokopi, wawancara, 23 November.

Hutomo, M. Y. (2000). Pemberdayaan Masyarakat Dalam Bidang Ekonomi. Yogyakarta: Adiyana Press.

Ibnu Abidin. ( t.th). Radd Mukhtar 'ala al Darr al- Mukhtar. Mesir: alAmariyyah.

Ibrahim. (2009). Tambo Alam Minangkabau: Tatanan Adat Warisan Nenek Moyang Orang Minang. Bukittinggi: Kristal Multimedia.

Ibrahim Anis. (1972). Al- Mu'jam AlWasith. Kairo: Dar Ihya At- Turast Al- Arabiy.

Jefrizal. (2016). Pengusaha Fotocopi, wawancara, 23 November.

Kartasasmita, G. (1996). Pembangunan untuk Rakyat. Jakarta: PT Pustaka CIDESINDO.

Mansoer. (1970). Sejarah Minangkabau. Jakarta: Bhratara.

Moesa, E. (2000). Introduction. Dalam R. a. Fundamentalism. Oxford: One World Publication.

Mujahidin, A. (2017). Peranan Kearifan Lokal (Local Wisdom) Dalam Pengembangan Ekonomi Dan Perbankan Syariah Di Indonesia. JURIS (Jurnal Ilmiah Syariah), 15(2), 153. 
Naim, M. (2013). Merantau: Pola Migrasi Suku Minangkabau. Jakarta: PT Raja Grafindo Presada.

Navis, A. (1984). Alam Takambang Jadi Guru. Jakarta: Grafiti Press.

Pendidikan, D. (2002). KBBI. Jakarta: Balai Pustaka.

Rafi'ah. (2016). Pengusaha Fotokopi, wawancara, 23 November.

Rintuh, C. M. (2005). Kelembagaan dan Ekonomi Rakyat. Yogyakarta: BPFE.

Sahiba Abdullahi Ammani, e. a. (2014). Zakah on employment income in Muslims majority states of. Procedia Social and Behavioral Sciences 164, 314.

Santoso, H. P. (1998). Ekonomi Pembangunan. Jakarta: Ghalia Indonesia.

Saputra, A. (2016). Pengusaha Fotokopi, wawancara, 23 November.

Saydam, G. (2010). Keajaiban Petatah Minang. Bandung: CV Pustaka Setia.

Sayuti, M. (2009). Kamus Ungkapan Adat Dan Budaya Alam Minangkaabu. Padang: Megasari.

Sugiyono. (2012). Memahami Penelitian Kualitatif. Bandung: Alfabeta.

Sulekale, D. D. (2014, Juni 25). wordpress.com/about/pemberdayaanmasyarakat-miskin-di-era-otonomidaerah . Dipetik Juni 18, 2019, dari https:/ / emperordeva.wordpress.co $\mathrm{m} /$ about/pemberdayaanmasyarakat-miskin-di-era-otonomidaerah/:https://emperordeva.word press.com/about/pemberdayaanmasyarakat-miskin-di-era-otonomidaerah/
Sumanto, D. (2018). Hukum Adat Di Indonesia Perspektif Sosiologi Dan Antropologi Hukum Islam. JURIS (Jurnal Ilmiah Syariah), 17(2), 181.

Suryana. (2006). Ekonomi Pembangunan: problematika dan Pendekatan. Jakarta: Salemba Empat.

Tamrin. (2016). Pengusaha Fotokopi, wawancara, 23 November.

Tulusan, F. M. (2014). Peningkatan Pendapatan Masyarakat Melalui Program Pemberdayaan di Desa Lolah II Kecamatan Tombariri Kabupaten Minahasa. Jurnal LPPM Bidang EkoSosBudKum, 94.

Turmudi, M. (Mei, 2018). Pemanfaatan Dana Corporate Social Responsibility. Al Izzah: Jurnal HasilHasil Penelitian-ISSN: 1978-9726 (p); 2541-0717 (e), 104-105.

Ully Hikmah Andini, M. S. (t.thn.). Pemberdayaan Ekonomi Masyarakat Dari Desa Tertinggal menuju Desa Tidak Tertinggal ( Studi Di Desa Muktiharjo Kecamatan Margorejo Kabupaten Pati). Jurnal Adsministrasi Publik (JAP), 7-11.

Wijaya, T. (2013). Metodologi Penelitian Ekonomi dan Bisnis Teori dan Praktek. Yogyakarta: Graha Ilmu.

Widiyanto. (2011). Effectivenesa of Qardh al Hasan Financing as a Poverty Allevation Model . Economic Journal of Emerging Markets.31

Yasrizal. (2016). Pengusaha Fotokopi, wawancara, 23 November.

Yusman. (2016). Pengusaha Fotokopi, wawancara, 23 November. 
Pola Akad dalam Pemberdaygann likonomi Masyarakat Perantau Atar \|2 219

Yusparman. (2016). Pengusaha Fotokopi, wawancara, 23 November.

Yusparman. (2016). Pengusaha Fotokopi, wawancara, 23 November.
Zainal. (2016) Pengusaha Fotokopi, wawancara, 23 November.

Zuhayliy, W. a. (1984). Figh al- Islamiy wa Adillatahu. Beirut: Dar al- Fikr. 